\title{
CARBON DIOXIDE AND LARGE VOLUME VENTILATION IN THE MANAGEMENT OF PATIENTS UNDERGOING CARDIAC SURGERY
}

\author{
Barbara Lipton, M.D., \\ aND MELVin KaHN, M.D."
}

Ir HAS LONG BEEN KNOWN that intermittent positive pressure breathing (IPPB) decreases cardiac output because the pumping effect of normal inspiration, which augments venous return, is lost when IPPB increases mean intrathoracic pressure. ${ }^{1}$ In addition, if IPPB produces hyperventilation, the resultant fall in $\mathrm{PaCO}_{2}$ (arterial carbon dioxide tension) will further reduce cardiac output ${ }^{2,3}$ and facilitate the induction of cardiac arrhythmias. ${ }^{4-8}$ These latter effects of acute respiratory alkalosis are magnified in the digitalized patient because of acute secondary hypokalaemia with production of digitalis toxicity. ${ }^{7-0}$ Hypocarbia also decreases cerebral blood flow ${ }^{10-12}$ and shifts the oxygen dissociation curve to the left, impairing release of oxygen from haemoglobin to all tissues. These effects of hyperventilation, although potentially serious in all patients, are most threatening in patients with limited cardiac reserve and enhanced myocardial irritability who are undergoing cardiac surgery.

However, it is in just these patients that hyperventilation is often necessary to maintain adequate oxygenation because of the association of ventilation-perfusion imbalance and intrinsic pulmonary pathology, secondary to the underlying cardiac disease. This investigation was initiated to seek a simple empirical solution to the problem.

\section{METHOD}

This study was carried out in 110 consecutive patients undergoing open or closed heart surgery for acquired cardiac disease. They varied in age from 17 to 78 years and in weight from 39 to $92 \mathrm{~kg}$.

All were premedicated with intramuscular injections of secobarbital and a belladonna drug $1 / 2$ hours prior to induction of anaesthesia. They were placed in semi-Fowler's position on the operating table and arterial and venous cut-downs were performed under local analgesia. Either the brachial or radial artery was used for blood sampling and direct recording of blood pressures. Arterial blood samples were drawn prior to induction of anaesthesia and one hour thereafter. $\mathrm{PaO}_{\mathrm{s}} \mathrm{pH}$, bicarbonate, $\mathrm{PaCO}_{2}$ and base deficit or base excess were determined by the Astrup method. ${ }^{13}$

Following a sleep dose of thiamylal sodium (200 to $400 \mathrm{mg}$ ) and oxygen by mask, a single dose of succinylcholine ( 40 to $100 \mathrm{mg}$ ) was given to facilitate endotracheal intubation. Anaesthesia was maintained with a 6-liter flow of nit-

-From the Department of Anaesthesiology and the Department of Medicine, Mount Sinaj School of Medicine, New York City. 
rous oxide and oxygen supplemented by intravenous Innovar morphine sulfate, or halothane, 0.25 to 1 per cent. A succinylcholine drip ( 0.4 per cent) was administered as needed. Controlled ventilation was established using a Bird Mark 4 and Mark 8 ventilator attached to a standard circle absorber anaesthetic machine. Tidal and minute volumes were monitored at the endotracheal tube on expiration by a recently calibrated Wright respirometer. Periodic hyperinflation was not employed. Tidal volumes were empirically set by adjusting the pressure on the Bird ventilator as had been done clinically in the past, i.e., by observing the patient's thoracic movement. The respiratory rates varied from 8 to 15 per minute.

The patients were divided into three groups, in which the management varied as follows:

Group A (48 patients) - ventilated as indicated above with the carbon dioxide absorber in place and no carbon dioxide added to the breathing mixture.

Group \& (27 patients) - identical to Group A but the carbon dioxide absorber was eliminated from the circuit.

Group c ( 35 patients) - identical to Group a but the carbon dioxide absorber was eliminated from the circuit and 2.5 per cent carbon dioxide was added to the breathing mixture.

In all patients peak inspiratory pressure, inspiratory flow rate, and preoperative pulmonary artery and left atrial or wedge pressures were recorded. Evidence of obstructive lung disease and the degree of lung compression by surgical packs and manipulation were also noted. Patients who developed moderate to severe hypotension were eliminated from the study.

The Radford nomogram ${ }^{14}$ was utilized retrospectively to calculate a predicted "ideal" tidal volume for each patient in this series in order to determine if the nomogram can be adapted for use in this group of patients.

\section{Results}

All patients were ventilated with tidal volumes which were 1.5 to 3.4 times as great as that recommended by Radford. ${ }^{14}$ The "tidal volume ratios" (actual tidal volume/predicted tidal volume) for the three groups of patients were similar (Table I) and indicated a significant degree of "hyperventilation." Of the 110 patients, 103 received 50 per cent oxygen in the input gas mixture, 5 received $40-49$ per cent and 2 received 33 per cent oxygen.

\section{Arterial Oxygen Tension $\left(\mathrm{PaO}_{2}\right)$}

The combined hyperventilation and increased oxygen resulted in satisfactory arterial oxygenation in all patients in all groups (Table I, Figure $\mathrm{l}_{\mathrm{A}}, \mathrm{B}, \mathrm{C}$ ). Mean $\mathrm{PaO}_{2}$ after one hour of anaesthesia for Groups $\mathrm{A}, \mathrm{B}$, and $\mathrm{C}$ was 215, 213, and 203 $\mathrm{mm} \mathrm{Hg}$ respectively, with no significant difference between the groups (Table I). Although the similarity of the groups is apparent, the marked variability in the $\mathrm{PaO}_{2}$ of individual patients is of greater importance. The correlations between the Pao.: and the "tidal volume ratio" were minimal and not significant (Figures $1_{\mathrm{A}, \mathrm{B}, \mathrm{C}}$ ) (Groups $\mathrm{A}, \mathrm{B}$, and $\mathrm{C} ; r=0.18,0.18$, and 0.13 respectively).

"Innovar is a 50:1 mixture of droperidol and fentanyl (McNejl Laboratories, Inc, Fort Washington, Pa.) 


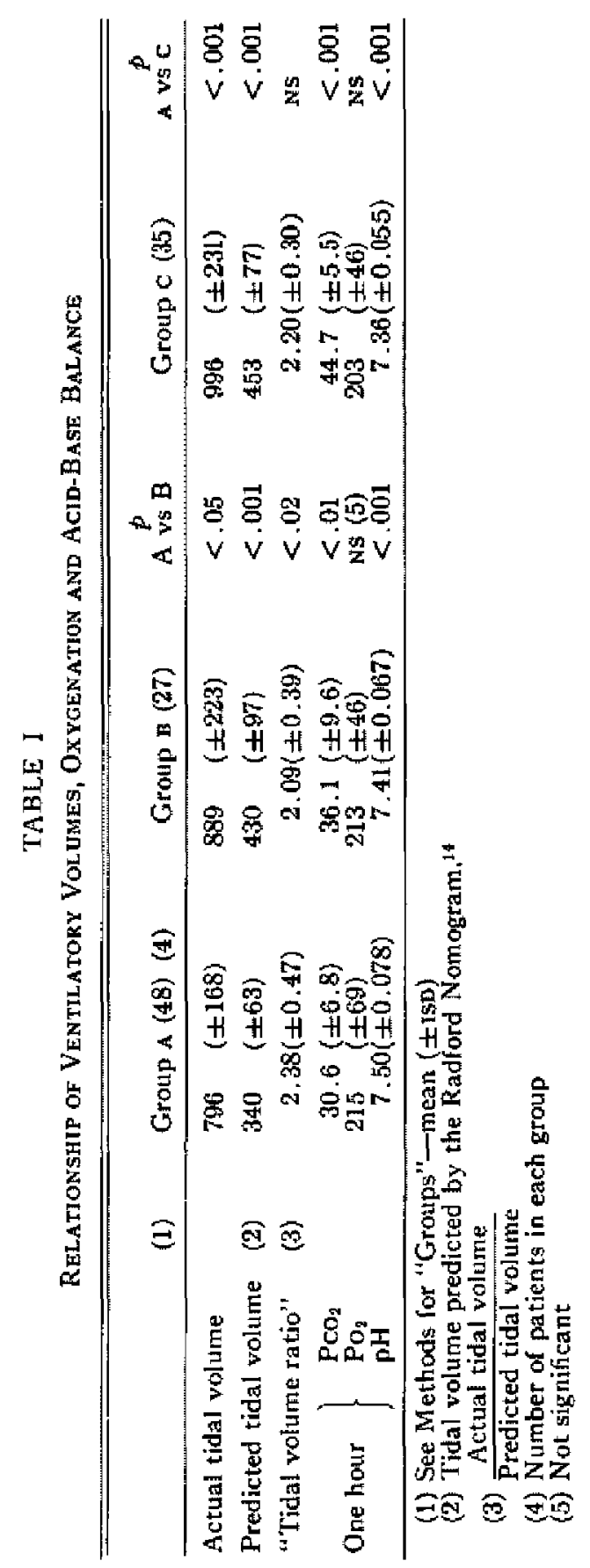




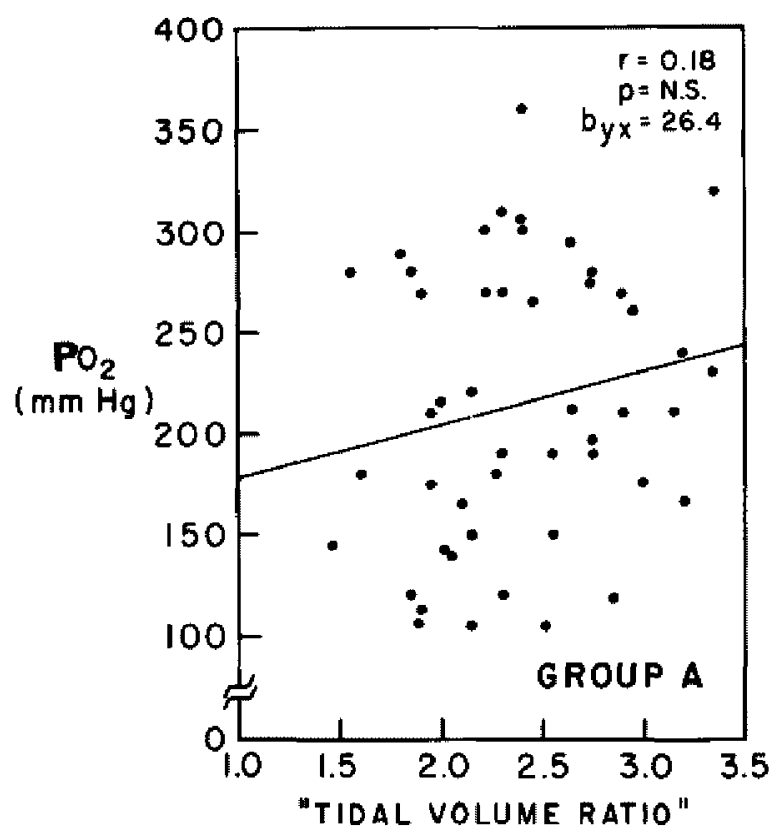

Foune 1A

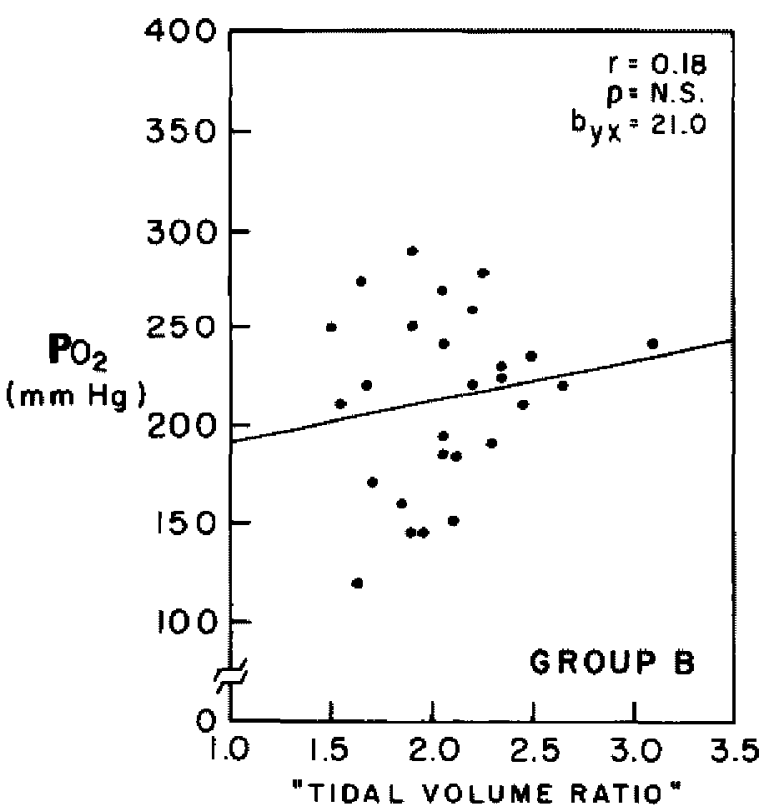

Frouax 1n 


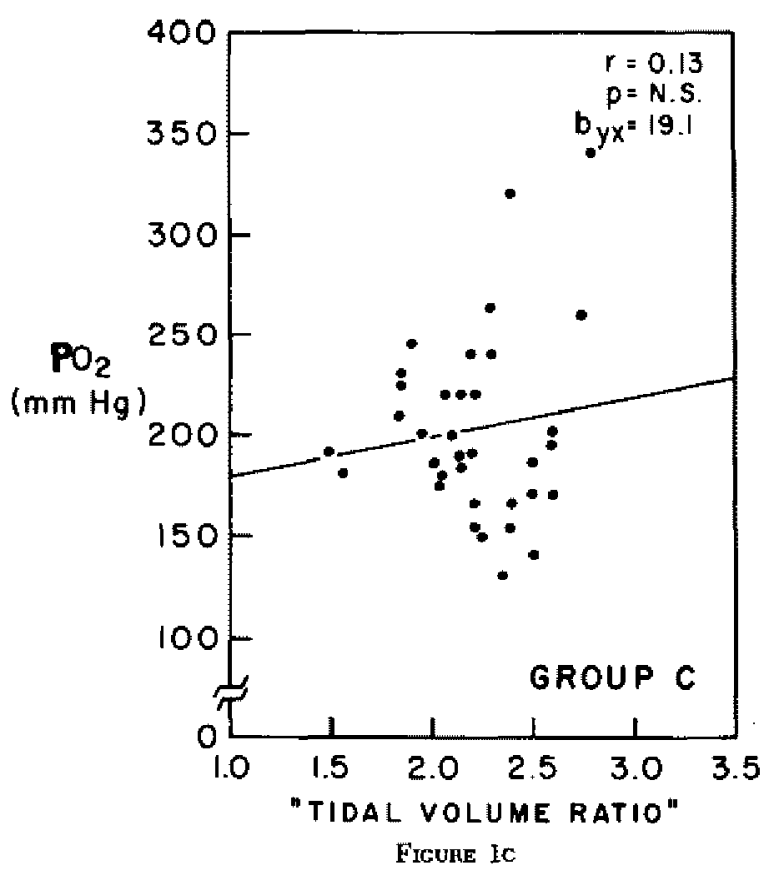

Figune 1. The relationship between $\mathrm{PaO}_{2}$ and tidal volume is shown. Adequate oxygenation was attained in all patients but the marked scatter and lack of intra-group correlation is apparent.

The frequent occurrence of relatively low $\mathrm{PaO}_{2}$ values in many patients receiving 50 per cent oxygen and "hyperventilation" was a result both of ventilation perfusion imbalance consequent to thoracic surgery with manipulation, collapse and packing of lung and intrinsic lung disease secondary to the cardiac pathology.

Arterial $\mathrm{PCO}_{2}$ and $p H$

The $\mathrm{PaCO}_{2}$ and $\mathrm{pH}$ after approximately one hour of anaesthesia were significantly different for the three groups (Table I). The mean $\mathrm{PaCO}_{2}$ for Groups $\mathrm{A}$, $B$, and $\mathrm{C}$ were $30.6,36.1$, and $44.7 \mathrm{~mm} \mathrm{Hg}$ respectively with similar intra-group distribution (standard deviation $+6.8,9.6$ and $5.5 \mathrm{~mm} \mathrm{Hg}$ ). In all three groups a significant correlation existed between the $\mathrm{PaCO}_{2}$ and "tidal volume ratio" (Figures $2 \mathrm{~A}, \mathrm{~B}, \mathrm{C})(r=-0.47,-0.53$, and $-0.4 \mathrm{I}$ for Groups $\mathrm{A}, \mathrm{B}$, and $\mathrm{c}$ respectively In Groups $\mathrm{B}$ and $\mathrm{c}$, in which the carbon dioxide absorber was removed, the $\mathrm{Paco}_{2}$ was significantly less dependent on ventilation after 2.5 per cent carbon dioxide was added to the breathing mixture (Group $\mathrm{c}$ ). This can be appreciated from an examination of Figures $2 \mathrm{~s}$ and $2 \mathrm{c}$. The slope of the regression of these two variables, i.e., ventilation and $\mathrm{PaCO}_{2}$ is twice as great in Group $\mathrm{B}\left(b_{y x}=-13.2\right)$ as in Group $\mathrm{c}\left(b_{y x}=-7,4\right)$. This suggests that a greater latitude in ventilatory volume is permissible in the Group $c$ patients to attain a homogeneous result within a desired range of $\mathrm{PaCO}_{2}$ values.

The mean arterial $\mathrm{gH}$ paralleled the $\mathrm{PaCO}_{2}$ (7.50, 7.41 and 7.36 units for Groups $A, B$, and $C$ ) since the buffering capacity of each group was not appreciably dif- 


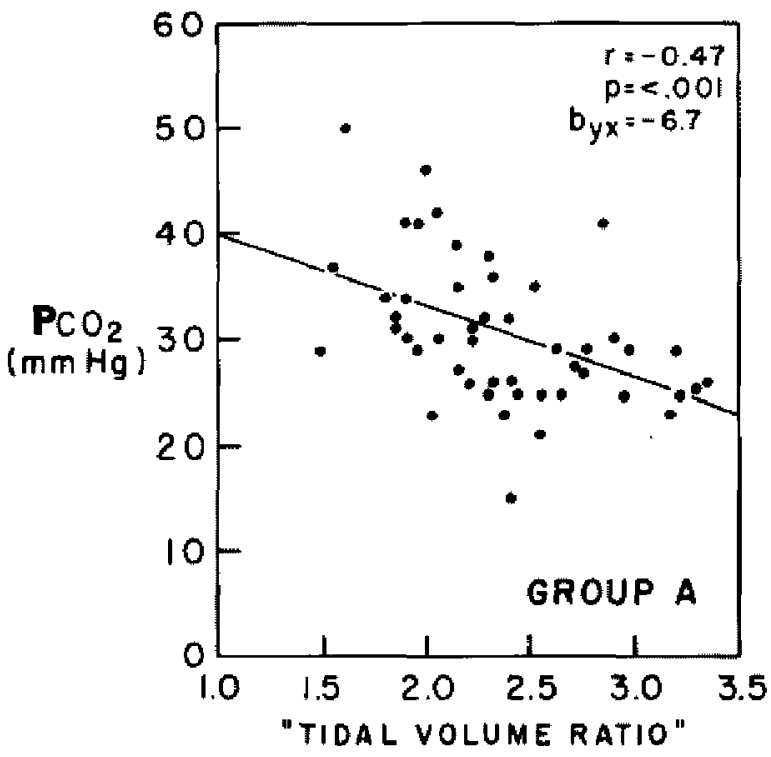

Figure 2A

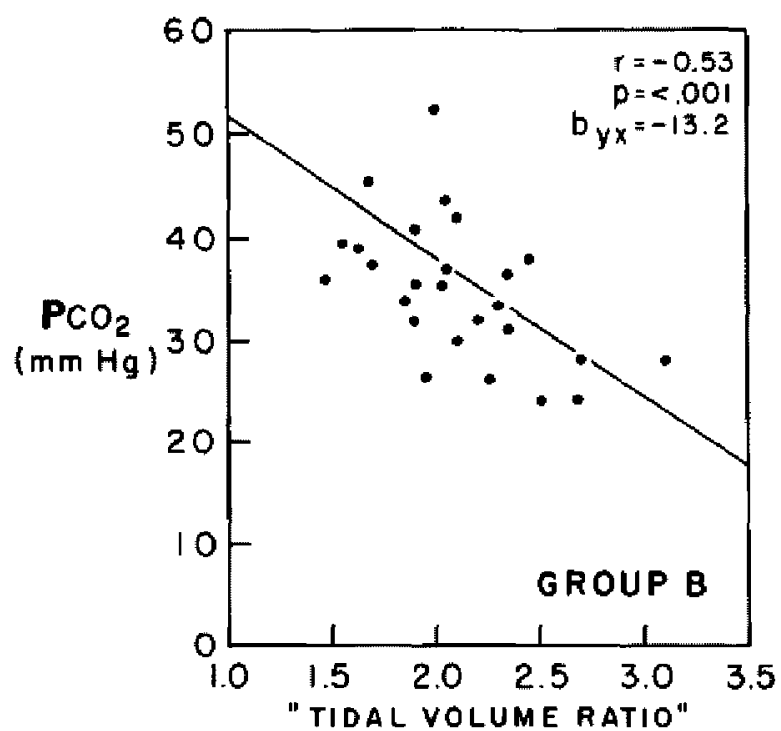

Figune 2a 


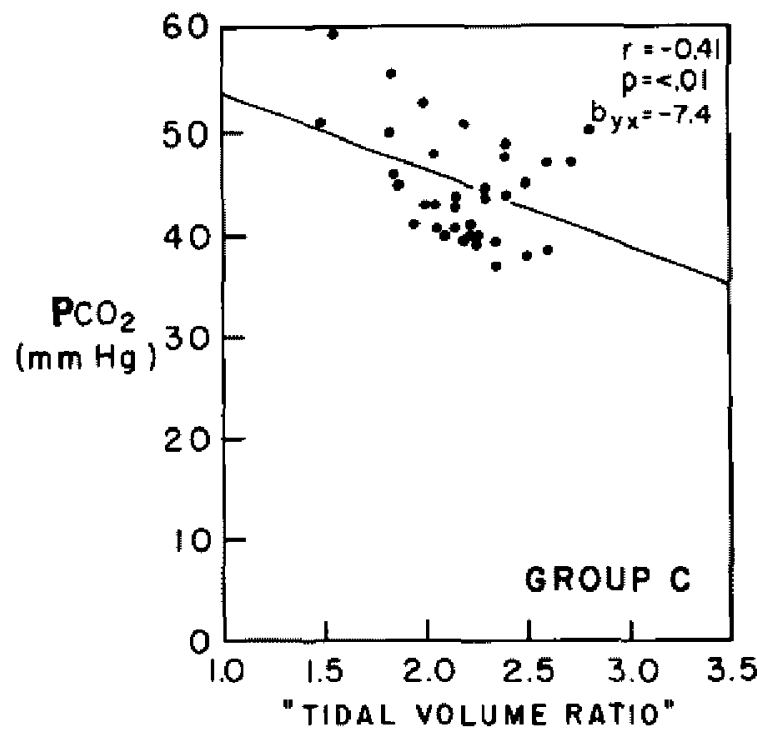

FTGURE $2 \mathrm{C}$

Froure 2. The relationship between $\mathrm{PaCO}_{3}$ and tidal volumes is shown. A significant correlation exists in each group between these parameters. The frequent occurrence of significant hypocarbia in Groups $A$ and $B$ is apparent. This contrasts with the relative homogeneity of Group $c$.

ferent. The greatest percentage of patients were protected from alkalosis without producing severe acidosis when 2.5 per cent carbon dioxide was administered with the absorber removed from the anaesthetic circuit (Figure 3, Group c). An arterial $\mathrm{pH}$ of between 7.28 and 7.43 units was found in 14 per cent, 63 per cent and 88 per cent of the patients in Groups $\mathrm{A}, \mathrm{B}$, and $\mathrm{C}$ respectively (Figure 3 ). More significant acidaemia (ph 7.20-7.27) was observed in only 4 per cent of the Group B patients and 6 per cent of the Group c patients. (In a series of only 6 patients in whom 5 per cent carbon dioxide was administered with the absorber removed, arterial pH was less than 7.27 in half and the use of this gas mixture was therefore discontinued.) However, alkalosis was a frequent occurrence in the patients in Groups $\mathrm{A}$ and $\mathrm{B}$ but rare in the patients in Group $\mathrm{C}$. An arterial $\mathrm{pH}$ greater than 7.44 was observed in 88 per cent of Group $A$ and 33 per cent of Group B but in only 6 per cent of Group c patients (Figure 3 ). This "protection" from alkalosis by the use of 2.5 per cent carbon dioxide in the breathing mixture is further emphasized by the fact that the highest $\mathrm{pH}$ in any Group $\mathrm{c}$ patient was 7.48 , a level which was exceeded by 65 per cent of the Group a patients and 15 per cent of the Group в patients.

\section{Discussion}

Even in a group of patients with normal cardiopulmonary function undergoing surgery of the abdomen and extremities, minute volume during IPPB must be increased over spontaneous ventilation to achieve a $\mathrm{PaO}_{2}$ equal to that observed during spontaneous ventilation. ${ }^{15}$ This has been attributed to disturbed ventilation- 


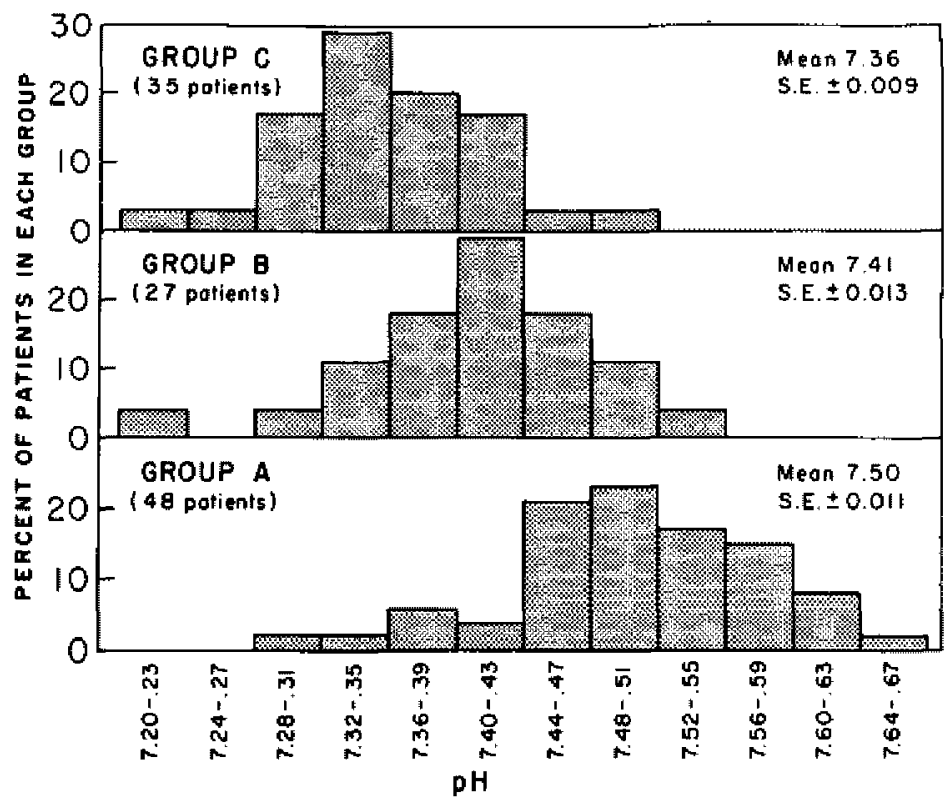

Fraune 3. The distribution of arterial $\mathrm{pH}$ in the patients in each group is shown. (See text for details.)

perfusion ratios. The problem is magnified in patients with cardiac disease who not only have a diminished cardiac output but also secondary pulmonary changes resulting from long-standing oedema and hypertension. Added to the inherent physiological problems are those of surgery of the thorax which enhances the ventilation-perfusion derangements. As noted in this study, in order to maintain the $\mathrm{PaO}_{3}$ at safe levels (above $100 \mathrm{~mm} \mathrm{Hg}$ ) during cardiac surgery, large minute volume ventilation is mandatory in many patients, even with 50 per cent oxygen. Since retention of carbon dioxide is uncommon in patients with acute impairment of pulmonary ventilation-perfusion relationships, alveolar and arterial carbon dioxide tensions are reduced, often to dangerously low levels.

Respiratory alkalosis may have two unfavourable effects on the heart. A reduction in cardiac output has been shown to occur ${ }^{2-4}$ and myocardial irritability is enhanced with a propensity to arrhythmias. ${ }^{5,6}$ The digitalized patient is more prone to develop a serious cardiac arrhythmia in the presence of acute respiratory alkalosis because of the rapid production of extracellular hypokalaemia. ${ }^{8}$ Respiratory alkalosis impairs central nervous system function in at least two ways. It decreases cerebral blood flow ${ }^{11-12}$ and shifts the oxyhaemoglobin dissociation curve to the left (Bohr effect), so limiting oxidative metabolism. Since patients undergoing cardiac surgery, particularly with the use of extracorporeal circulation, are prone to postoperative cerebral dysfunction, further potential impairment of cerebral metabolism should be avoided by minimizing the risk of respiratory alkalosis.

It has been shown that normal or slightly elevated carbon dioxide tension is 
essential to the maintenance of adequate tissue perfusion in anaesthetized patients. ${ }^{16}$ Huckabee ${ }^{17}$ has shown that respiratory alkalosis is accompanied by increased lactic:pyruvic acid ratios. Allan-Carson ${ }^{18}$ has found that if respiratory alkalosis is produced, greater anaerobic metabolism occurs during hypothermia than in subjects maintained at normal ventilation and arterial $\mathrm{pH}$.

Radford ${ }^{14}$ designed a nomogram to predict the tidal volume and respiratory rate required to achieve normal alveolar ventilation in patients with normal respiratory and circulatory function. In recent years the safety of IPPB from the standpoint of oxygenation has been questioned. ${ }^{10,20}$ An increase in physiologic dead-space and ventilation-perfusion inequality have been demonstrated during IPPB in both awake and anaesthetized subjects and the tidal volume as predicted with the Radford nomogram ${ }^{14}$ has been discarded and much larger ventilatory volumes have been employed during IPPB. This eliminated the problems of hypoxaemia but introduced those of hypocarbia which were described above.

A number of methods have been suggested to maintain a normal $\mathrm{PaCO}_{2}$ in the presence of large ventilatory volumes. These techniques are unsuitable for the type of patient in this study because they frequently produce respiratory alkalosis ${ }^{21-24}$ or because of the huge dead-space needed. ${ }^{25}$

This study shows that respiratory alkalosis can be avoided while maintaining suitable oxygenation without risk of respiratory acidaemia in patients undergoing cardiothoracic surgery. Empirically this can be predictably obtained by the use of at least 6 liters of fresh gas, tidal volumes 2.0 to 2.5 times that calculated from the Radford nomogram, ${ }^{14}$ removal of the carbon dioxide absorber and the addition of 2.5 per cent carbon dioxide and 50 per cent oxygen to the inspired mixture. This technique is intended as a simple guide for initiating a reliable method of IPPB in patients undergoing surgery. It is not intended to replace arterial blood gas analysis. The virtues of our method are that no additional equipment is necessary and that oxygen homeostasis is regulated independently of carbon dioxide elimination.

\section{SUMMARY}

Respiratory alkalosis produced by IPPB in patients undergoing cardiothoracic surgery may reduce cardiac output, facilitate the induction of cardiac arrhythmias, induce digitalis toxicity, decrease cerebral blood flow and shift the oxyhaemoglobin dissociation curve to the left. These effects are most threatening in patients undergoing cardiac surgery whose cardiac reserve is poor and whose myocardial irritability is enhanced. This study was carried out in 110 patients who underwent either open or closed heart surgery for acquired cardiac disease. Three groups of patients were each managed in a different way. Group A (48 patients) was ventilated with the carbon dioxide absorber in place and no carbon dioxide added to the breathing mixture; Group B (27 patients) had the carbon dioxide absorber eliminated from the circuit; and Group $c$ ( 35 patients) had the carbon dioxide absorber eliminated from the circuit and 2.5 per cent carbon dioxide added to the breathing mixture. All patients were ventilated with tidal volumes which were 1.5 to 3.4 times greater than those recommended by Radford. All had satisfactory $\mathrm{Pao}_{2}$. The $\mathrm{PaCO}_{2}$ and $\mathrm{pH}$ were significantly different for the three groups. The mean $\mathrm{PaCO}_{2}$ for Groups $\mathrm{A}, \mathrm{B}$, and $\mathrm{C}$ were $30.6,36.7$, and 44.7 
$\mathrm{mm} \mathrm{Hg}$ respectively. An arterial $\mathrm{pH}$ greater than 7.44 was observed in 88 per cent of Group A and 33 per cent of Group B, but in only 6 per cent of Group $C$ patients. A greater latitude in ventilatory volume was permissible in Group $\mathrm{C}$ subjects to attain a homogeneous result within a desired range of $\mathrm{PaCO}_{2}$ levels. Severe acidaemia was not a problem. This study shows that respiratory alkalosis can be avoided while maintaining suitable oxygenation without risk of respiratory acidaemia in patients undergoing cardiac surgery. Empirically, this can be predictably obtained by the use of at least 6 liters of fresh gas, tidal volumes 2.0 to 2.5 times that calculated from the Radford nomogram, removal of the carbon dioxide absorber and addition of 2.5 per cent of carbon dioxide and 50 per cent of oxygen to the inspired mixture.

\section{RÉSUMÉ}

L'alcalose respiratoire produite par la IPPB chez des malades soumis à de la chirurgie cardiothoracique peut diminuer le débit cardiaque, 'prédisposer à l'apparition d'arythmies, favoriser une intoxication digitalique, diminuer le débit sanguin cérébal et pousser vers la gauche le courbe de dissociation de l'oxy. hémoglobine. Ces effets sont plus pénibles pour les malades soumis à la chirurgie cardiaque dont la réserve cardiaque est limitée et dont l'irritabilité cardiaque est accrue. Notre étude a porté sur 110 malades soumis à de la chirurgie cardiaque à coeur ouvert ou fermé pour des maladies cardiaques acquises. Nous avons partagé les malades en trois groupes et chacun de ces groupes a été traité de façon différente. Le groupe a (48 malades) a été ventilé alors que l'absorbant du $\mathrm{CO}_{2}$ était en place et nous n’avons pas ajouté de $\mathrm{CO}_{2}$ dans le mélange inspiré; le groupe в (27 malades) a été ventilé sans absorbant de $\mathrm{CO}_{2}$ et nous avons ajouté au mélange inspiré un taux de 2.5 pour cent de $\mathrm{CO}_{2}$. Nous avons ventilé tous les malades avec un air courant qui était de 1.5 à 3.4 fois plus grand que ceux mentionnés par Radford. Tous les malades avaient une Pao.. satisfaisante. $\mathrm{La} \mathrm{PaCO}_{2}$ et le $\mathrm{pH}$ étaient légèrement différents d'un groupe à lautre. Pour chacun des groupes A.B.C., la $\mathrm{PaCO}_{2}$ moyenne était respectivement de $30.6,36.7$ et $44.7 \mathrm{~mm} \mathrm{Hg}$. Chez 88 pour cent des malades du groupe $\mathrm{A}$, nous avons observé un $\mathrm{pH}$ au-dessus de 7.44; chez les malades du groupe $\mathrm{B}$, la même observation a été faite chez 33 pour cent des malades et chez les malades du groupe $c$, seulement chez 6 pour cent.

Chez les malades du groupe $c$, nous avons toléré une plus grande latitude dans le volume de ventilation pour obtenir un résultat homogène en deça de limites désirées des taux de $\mathrm{PaCO}_{2}$. L'acidhémie grave n'a pas été un problème. Cette étude prouve que l'alcalose respiratoire peut être évitée tout en maintenant une oxygénation convenable sans risque d'acidhémie respiratoire chez des malades soumis à la chirurgie cardiaque. Empiriquement, ceci peut être obtenu de façon prévisible en utilisant un débit d'au moins 6 litres de gaz frais, un air courant de 2 a 2.5 fois plus grand que celui mentionné dans le nomogramme de Radford, en enlevant l'absorbant du gaz carbonique $\left(\mathrm{CO}_{2}\right)$ et l'addition de 2.5 pour cent de $\mathrm{CO}_{2}$ et 50 pour cent d'oxygène dans l'air inspiré.

ACKNowledgements

We wish to thank Dr Robert S. Litwak, Professor of Surgery and Chairman of 
the Division of Cardiothoracic Surgery for allowing us to conduct this study in his operating room.

\section{REFERENCES}

1. Cournand, A, Mothey, H, L., Wefks, L., \& Richards, D. W., Jn, Physiological studies of effects of intermittent positive pressure breathing on cardiac output in man. Am. J. Physiol., 152: 162 (1948).

2. TheYe, R. A., Mil.De, J. H. \& MicheNFelden, J. D. Effect of hypocapnia on cardiac output during anesthesia. Anesthesiology, 72; 778 (1966).

3. Prys-7loberts, C., Kelman, G. R., Katn, M. L., Greenbaum, R., \&ay, J. Cardiac output and blood carbon dioxide levels during halothane anesthesia in man. Brit. J. Anaesth., 39: 687 (1967).

4. Morgan, B. C., Crawford, E. W., Hohnbein, T. F., Maftin, W. E. \& Gunthehoth, W. G. Hemodynamic effects of changes in arterial carbon dioxide tension during intermittent positive pressure ventilation. Anesthesiology, 28: 886 ( 1967 ).

5. Cullen, D. J., Eger, E. I., ir \& Gregony, G. A. The carcliovascular effects of carbon dioxide in man, conscious and during cyclopropane anesthesia. Anesthesiology, 31: 407 (1969).

6. WHIGHT, B. D. \& DIGIOVANNI, A. J. Respiratory alkalosis, hypokalemia, and repeated ventricular fibrillation associated with mechanical ventilation. Anesth. \& Aanlg., 48: 467 (1969).

7. Fremma, R. J. \& Younc, W. G., JR. The metabolic effects of mechanical ventilation and respiratory alkalosis in postoperative patients. Surgery, 56: 36 (1964).

8. Scrimaner, G. H., Fremont-Smith, K., \&urnelx, J. M. The effect of acute respiratory acidosis on the intemal equilibrium of potassium. J. Clin. Invest., 34: 1276 (1955).

9. Hali., K. D. \& Vantanian, $V$, Control of serum potassium levels in the hyperventilated postoperative cardiac patient. South. M. J., 61: 416 (1958).

10. SokoLorf, $L$. The action of drugs on the cer ebral circulation. Pharmacol Rev, 11:1 (1959).

11. Alexander, S. C., Cohen, P. J., Wollman, H, Smith, T. C., Reivich, M., \& Vandeh Moles, R. A. Cerebral carbohydrate metabolism during hypocarbia in man. Anes. thesiology, 26: 624 (1965).

12. Froman, C. Adverse effects of low carbon dioxide tensions during mechanical over-ventitation of patients with combined head and chest injuries. Brit. J. Anaesth., 40:383 (1968).

13. ANDERSON, O. S. \& ENGEL, K. A. A new acid-base nomogram. An improved method for the calculation of the relevant blood acid-base data, Scandinav. J. Clin. \& Lab. Invest., I2: $177(1960)$.

14. RaDFond, E. P., JR. Ventilation standards for use in artificial respiration. J. Appl. Physiol., 7: $451(1955)$.

15. Gold, M. I. \& Helmich, M. Ventilation and blood gases in anesthetized patients. Canad. Anaesth. Soc. J., 14: 424 (1967).

16. Johnstone, M. Hypocapnic vasoconstriction during halothane anaesthesia in surgical patients. Brit. J. Anaesth, 40: 602 ( 1968),

17. HuCKABEE, W. E. Relationship of pyruvate and lactate during anaerobic metabolism. Effects of infusion of pyruvate or glucose and of hyperventilation. J. Clin. Invest, $37: 244$ (1958).

18. Allan-Carson, S. A. \& Morris, L. E. Controlled acit-base status with cardiopulmonary bypass and hypothermia. Anesthesiology, 23: 618 (1962).

19. Nuni, J. F., Bergman, N. A., \& Colmman, A. J. Factors intluencing the arterial oxygen tension during anesthesia with artificial ventilation. Brit. J. Anaesth.., 37: 898 (1965).

20. Bentixen, H. H., Hedley-Whyte, J., \& Laver, M. B. Impaired oxygenation in surgical patients during general anesthesia with controlled ventilation. A concept of atelectasis. New England J. M., 269: 991 (1963).

21. Baraka, A., SMITH, C. O., \& ShrofF, P. E. Controlled nomocarbia duning IPPB with the Emerson anesthetic ventilator. Anesthesiology, 32: 369 (1970).

22. OCBO, E. M. \& TERrY, R. N. Proposed formula for ventilatory requirements in apneic anes. thetized patients. Anesth. \& Analg, 48:455 (1969).

23. KeEri-Szanto, M. Isokapnic ventilation during surgical operations: Description of equipment and first results. Anesth. \& Analg, 49: 406 (1970).

24. Suwa, K. \& Yamamura, $\mathrm{H}$. The effect of gas inflow on the regulation of $\mathrm{CO}_{2}$ Ievels with hyperventilation during anesthesia. Anesthesiology, 33: 440 (1970).

25. Suwa, K., Geffin, B., Pontoppidan, H., \& Bendixen, H. H. A Nomogram for deadspace requirement during prolonged artificial ventilation. Anesthesiology, 29: 1206 (1968). 